\title{
Maintaining Local Wisdom Aa Nationalism Measurement
}

\author{
Purwati Anggraini $^{1 *}$, Joko Widodo2, Candra Rahma Wijaya Putra ${ }^{3}$ \\ Universitas Muhammadiyah Malang, Jalan Raya Tlogomas 246 Malang, Jawa Timur 65144, \\ Indonesia ${ }^{1,2,3}$ \\ \{poer1979ang@gmail.com ${ }^{1}$ \}
}

\begin{abstract}
The attitude of nationalism of the younger generation is thought to have been eroded by modernization and globalization. This will endanger the unity and integrity of the Indonesian nation. This study aims at describing the local wisdom forms held firmly by public figures to represent nationalism. This research is a descriptive qualitative study. The objects of this study are the threewinning of the novel-writing contest of Seberapa Indonesiakah Kamu?; the novels are entitled Karena Aku Tak Buta by Redy Kuswanto, Kaki Langit Talumae by Wishnu Mahendra, and How to Love Indonesia by Buma M. Sembiring. This study's result shows that The form of local wisdom practiced by the main character in his life is to maintain and develop values, traditional arts, and traditions passed on by previous generations. The attitude of love for the country shown by the younger generation of Indonesia is affected by the pattern of education in the family, the community, and the figures' problems. The nationalism is manifested by figures in maintaining local wisdom that applies to Indonesian society. Local wisdom is passed on to the younger generation through education both within the family and in society. This local wisdom continues to strengthen and the awareness of leaders in solving problems in the surrounding environment. Local wisdom that is held firmly by figures not only affects their lives but also has a positive impact on the surrounding environment.
\end{abstract}

Keywords: nationalism; novel; local wisdom

\section{Introduction}

Characters are inherent in humans and can be formed and developed through learning at school, guidance at home, and environmental influences. A character must be developed based on the community's traditional values and integrated with the existing community context, such as the community's culture and the religion of the majority of the community (Zuriah, 2016).

The character in a literary work is a character inherent in a character, which is deliberately described by the writer both descriptively and expressed in a dialogue among characters as one of the requirements for literary works' structure. By giving characters or better known as 
characterization of characters, the writer wants to give the reader a message because one of the functions of literary works is dulce et utile (Al-Hafizh, 2012). The problem that arises is that people are starting to ignore positive things that are the legacy of their ancestors that have been written in literary works (Herawan and Sudarsana, 2017), which is marked by a moral crisis. The moral crisis that is currently hitting this nation requires the immediate revitalization of the nation's culture (Hobsbawm through Setiawan, 2013).

One way to revitalize the noble values of the nation's culture can be realized by reading literary works that contain local wisdom. Many literary works contain character education and shape society with knowledge rooted in wisdom (Rondiyah, Wardani, Saddhono, 2017). Reading literary works of local wisdom can foster a sense of love for the country. The sense of pride in the homeland is a form of national character education that must be possessed by all people.

Readers of literary works can catch literary works' messages if the readers understand and appreciate the plot of the story presented (Al-Ma'ruf, 2006). In this process, readers will be able to appreciate literary works well. In closing, readers can internalize the values contained in literary works into themselves. Thus, consciously or unconsciously, the reader will try to develop his character after reading the novel.

The problem of nationalism appears in several novels. The character issues raised are motivated by various problems, one of which is social problems, which is always interesting to discuss, given that these problems continue to grow along with population growth. There are several studies related to environmental influences, local wisdom, and character. Anggraini (2015) shows that the family, school and community environment greatly influence the role of figures. A good environment will provide opportunities for characters to do good. Related to research on local wisdom in Indonesian language text books for grade X high school students, Anggraini and Kusniarti (2015) said that the contents of language textbooks for grade X high school students contained several local wisdoms that could be developed as a learning model. This local wisdom-based learning model is important because in addition to local wisdom it can make humans wiser, local wisdom is also threatened not to be passed on to the next generation. Several social problems can contribute to developing the character of nationalism. Through the research object of the winning novel "Seberapa Indonesiakah Kamu?", The researcher revealed the defense of local wisdom as a manifestation of the younger generation's nationalism attitude. This study's results are appropriate to be expressed, considering that as the next generation, young people are obliged to understand their country first (Ismawati and Suyanto, 2015).

\section{Method}

This research is a qualitative research with descriptive methods. The purpose of this study is to describe the preservation of local wisdom carried out by figures to show their nationalistic attitude. The object of this research is the $-1^{\text {st }} 3^{\text {rd }}$ winner of novel writing contest Seberapa Indonesiakah Dirimu?; The novel is entitled Karena Aku Tak Buta, by Redy Kuswanto, Kaki Langit Talumae by Wishnu Mahendra, and How to Love Indonesia by Buma M. Sembiring. The data collection techniques used were (1) reading the three research objects, including formulating the research formulations and objectives. The problem raised in this study is that social problems have an impact on the decline in the nationalism of the younger generation. One of the efforts to overcome this problem is to 
explore the concept of preserving local wisdom carried out by the figures in the object of this research as a measure of the nationalism attitude of the younger generation; (2) preparing data collection tables containing research indicators that have been adjusted to the theory of local wisdom and nationalism. The indicator of local wisdom referred to is the values prevailing in society, traditional arts, and traditions inherited from previous generations. The indicators of nationalism in question are citizenship nationalism, ethnic nationalism, romantic nationalism, cultural nationalism, state nationalism, and religious nationalism; (3) enter data into the data filter table, (4) perform coding. The data analysis techniques are as follows: (1) Checking the completeness and variation of the data, (2) describing and interpreting the data, (3) drawing conclusions.

\section{Result}

Novel entitled Karena Aku Tak Buta, by Redy Kuswanto, has two main characters, namely Zad and Gendis. Gendis comes from a rural area that gets the benefit of a scholarship for her study. Zad, who is the son of a rich person, often spends his time having fun. Zad studies on the same campus with Gendis. Meanwhile, Gendis is a young woman from Gopakan hamlet, Ngargomulyo. Gendis became one of the young volunteers at the Kolong Tangga Museum and devoted himself to the Merti Dusun cultural activities and the Dolanan Bocah Festival. The closeness of Gendis and Zad finally turned Zad into a figure who loves local culture. The three friends of Zad still forbid Zad to assist with cultural events they did not know. The argument broke Zad's friendship with his best friend.

Zad resolved this problem by trying to convince his three friends to care about preserving Indonesian culture. Zad also tries to donate his wealth, energy, and thoughts so that Indonesian culture can prevail. Zad's actions in participating in developing culture show that a positive environment can change Zad's attitude from negative to positive. Zad tries to adjust his attitude on prevailing local wisdom. Local wisdom that appears in Zad's behavior is manifested in the sense of solidarity, pride, and admiration for Indonesian culture. Zad involved himself as a young volunteer to raise and introduce the Buddhayah Shack community and Kolong Tangga Museum to the broader community through website design. A sense of confidence and care for the preservation of Indonesian culture was also manifested in Merti Dusun Gopakan by giving flyers, leaflets, and posters to foreigners to participate in the event.

The efforts made by Zad can change the economy and social life of the people of the Gopakan hamlet. The Merti Dusun event, which many foreign tourists attended as an effort to introduce the culture of the Gopakan hamlet, was also supported by the hard work of the main characters, Zad and Gendis. Zad's brave nature and initiative were able to arouse his friend's sense of care for cultural preservation, as did Zad's father. Zad has proven that he is not blind to Indonesian culture, which is slowly starting to erode. If Gendis, as a village girl, can devote herself as a young volunteer without being paid, then Zad, who comes from a wealthy family, has more opportunities to introduce Indonesian culture

In the second novel, namely Kaki Langit Talumae by Wishnu Mahendra, the main character is a teenager named Asdar, who drops out of his education. Asdar comes from an underprivileged family, as well as the people in the neighborhood where he lives. Even though he came from a low-income family, the childhood of Asdar and his friends was always given directions by Grandma Resse to continue to struggle to make their hometown move forward. Grandma Resse is one of the respected figures in the village. It is the economic problems 
raised in this novel, especially the problem of the main character who is unable to realize his goal of continuing education.

The problems faced by Asdar have not dampened his enthusiasm to continue to struggle to build his hometown. Asdar migrated and worked in a rubber plantation. Asdar prefers to work within the country as a representation of his love for the country. Even though his foreman was a mean person, he was always kind to others, fair, diligent, brave, honest, consistent, and smart. Because of his good attitudes at work, eventually, Asdar had the opportunity to be trusted by his employer to manage a furniture shop. Finally, Asdar became a businessman by opening a beverage shop in the village and employing young people who had dropped out of school. The efforts made by Asdar raised the economy of the family and society in his hometown.

The efforts made by Asdar are a manifestation of his love for his hometown (Anggraini, 2018). Asdar also invited his friends to build his hometown as a small part of Indonesia. According to him, building a village and advancing it together will make this nation a strong country. Asdar also inspired his friends to be respectful to others, fair, diligent, brave, honest, consistent, and smart in doing small things to change his hometown. The change in his hometown is a manifestation of the progress of the Indonesian state. This storyline is in line with Rahman and Hidayat (2018) research, which states that awareness and a strong will can change any problematic situation.

The novel How to Love Indonesia by Buma M Sembiring is the third winner in a novelwriting competition with the theme "Seberapa Indonesiakah Dirimu?". In this novel, there are three main characters, namely Dea, Suri, and Dobe. Dea has an attitude of indifference to the Indonesian people. According to Dea, Indonesia has always been ranked the worst globally, starting from cooperation, environmental awareness, and even history. Dea's ignorance became prominent when she took the History major in college. Her choice creates conflict in the novel to appear initially. Dea was unable to answer simple questions about her hometown's origin at the exam time, causing her bad score, namely an E, even though her father was a lecturer. His father was very disappointed and angry with him.

The problem was resolved by asking the lecturer for corrections on the value. Dea visited the lecturer's house twice. First, Dea went to Pak Doan, her history lecturer, accompanied by her best friend, Suri. The initial intention to visit Pak Doan's house was to focus on how the lecturer could improve his grades, but it did not work. Pak Doan has a strong view of being assigned the E value for Dea. Not only that, but Pak Doan also compared him to Suri, who cared more about the Indonesian people, because Suri was able to answer questions that Pak Doan asked Dea quickly. The situation was what ultimately worsened the situation and triggered conflict between Dea and Suri. Second, Dea went to Pak Doan's house alone without Suri accompanied. This time Dea focused more on why the question was raised in the exam questions. Pak Doan said that Indonesians should love their country as much as they love their mothers. Pak Doan's answer touched Dea's heart, which in the end had an impact on Dea's unwillingness to correct her value again. In her heart, Dea is determined to improve herself and love Indonesia with all her heart.

Dea tries to solve problems with local wisdom. This effort is manifested by the main character's awareness to love his country with all his heart like he loves his mother. In this way, conflict resolution fosters a sense of "belonging" to Dea towards the Indonesian state. This awareness is shown by her everyday life behavior, namely being more sensitive to the surrounding environment. For example, the main character throws garbage in its place, likes batik, and even learns about the area's customs. Not only that, Dea realized that the most crucial thing was concrete actions that could be done for the benefit of the nation and state. 
The change in attitude shown by the main character was limited, but he also invited other figures to love Indonesia by making his parents aware of teaching education to love the country. Because Dea resolved problems with a sincere heart and accepted the value she deserved, she motivated other people to be more sensitive to the homeland.

\section{Discussion}

Local wisdom in the three novels proves that local wisdom can encourage characters to be wiser in their attitudes. The values passed on by their ancestors were ultimately well preserved. This situation certainly inspires readers significantly and provides insight into the importance of preserving local wisdom as a form of nationalism. Wildan (2013) argues that the local wisdom's function in the novel is to maintain the values of traditions and customs that have been going on for generations.

The local wisdom contained in these literary works shows that the inheritance efforts must be carried out continuously so that the next generation will know, understand, and at the same time, preserve the local wisdom because local wisdom can be used as a medium for character strengthening (Fawziah, 2017; Setianingsih, 2019), both at school, within the family, and in the community.

The preservation of local wisdom can be used as an indicator of the attitude of nationalism. Nationalism does not have to be shown by doing big things. Conversely, an attitude of nationalism can be shown by doing small things, such as doing something to advance one's hometown. As Nurhidayah's research (2019) results, returning to your hometown can show one's nationalistic attitude. The locality is a hereditary cultural heritage that can strengthen nationalism, increasing the sense of pride in one's area (Nugrahani et al., 2020).

\section{Conclusion}

The characters' wisdom of attitude is shown by the three novels, who are the study objects. The locality is very clearly described in the attitudes and behavior of the main character. This attitude indicates a character's nationalism, namely loving and developing Indonesian culture and loving the Indonesian state as a character who loves his mother. Literary works can actually be used as a medium to shape and develop the character of nationalism. Readers can reflect on the literary work they read, then internalize the values contained in the literary work into themselves. Readers can see the character of the characters and take the positive side. Competition in the era of globalization and the swift currents of modernization cannot be avoided. However, this competition should not have an impact on the loss of people's identities and nor should it reduce the level of comfort of human life. Human behavior will certainly have various impacts. For this reason, it is necessary to determine a wise attitude so that the impact of human behavior does not lead to negative things. Seeing the great benefits of literary works, research that explores the wealth of literary works that can be utilized by society like this is very necessary, especially research on local wisdom in literary works that can be used to build and develop attitudes of nationalism in facing society 5.0. 


\section{References}

[1] Al-Hafizh, M. (2012). Menakar Fungsi Dulce Et Utile Karya Sastra Remaja Indonesia. In International Conference on Languages and Arts (pp. 445-452).

[2] Al-Ma'ruf, A. I. (2006). Dimensi sosial keagamaan dalam fiksi Indonesia modern fenomena perkawinan lintas agama dalam novel Keluarga Permana karya Ramadhan KH: Kajian semiotik.

[3] Anggraini, P. (2015). Penerapan Model Lingkaran Sastra dan Pedagogi Reflektif dalam Meningkatkan Kemampuan Mengapresiasi Sastra. KEMBARA: Jurnal Keilmuan Bahasa, Sastra, dan Pengajarannya (e-Journal), 1(1), 77-85.

[4] Anggraini, P., \& Kusniarti, T. (2015). The insertion of local wisdom into instructional materials of Bahasa Indonesia for 10th grade students in senior high school. Journal of Education and Practice (JEP), 6(3), 89-92.

[5] Anggraini, P. (2018). Representasi Karakter Cinta Indonesia dalam Novel Kaki Langit Talumae dan Pengembangannya Sebagai Media Pembelajaran (Representation of Nationalism in Novel Kaki Langit Talumae and Its Development as A Learning Media). Jurnal Bahasa, Sastra dan Pembelajarannya (JBSP), 8(1), 1-14.

[6] Fawziah, F. (2017). Nilai Karakter pada Kearifan Lokal dalam Karya Sastra. Andragogi: Jurnal Diklat Teknis Pendidikan dan Keagamaan, 5(2), 95-112.

[7] Herawan, K. D., \& Sudarsana, I. K. (2017). Relevansi Nilai Pendidikan Karakter Dalam Geguritan Suddhamala Untuk Meningkatkan Mutu Pendidikan Di Indonesia. Jurnal Penjaminan Mutu, 3(2), 223-236

[8] Ismawati, Y. T., \& Suyanto, T. (2015). Peran Guru PKN dalam Membentuk Sikap Cinta Tanah Air Siswa di SMA Negeri 1 Mojosari Kabupaten Mojokerto. Kajian Moral dan Kewarganegaraan, 2(3), 877-891.

[9] Nugrahani, F., AM, A. I., \& Widayati, M. (2020). Gerakan Literasi Sekolah Berbasis Kearifan Lokal dan Kontribusinya Bagi Pendidikan Karakter. Widyaparwa, 48(1), 50-64.

[10] Nurhidayah, S. (2019). Lokalitas dan Nasionalisme: Ruang Alternatif Antikolonial dalam Novel The Inheritance of Loss Karya Kiran Desai. Jurnal Pena Indonesia, 5(2), 107-118.

[11] Rahman, F., \& Hidayat, R. (2018). Kearifan Lokal dan Benturan Budaya Orang Indonesia di Negara Luar dalam Novel Edensor Karya Andrea Hirata. BAHASTRA, 38(1), 34-42.

[12] Rondiyah, A. A., Wardani, N. E., \& Saddhono, K. (2017, June). Pembelajaran Sastra Melalui Bahasa Dan Budaya Untuk Meningkatkan Pendidikan Karakter Kebangsaan Di Era Mea (Masayarakat Ekonomi Asean). In Proceedings Education and Language International Conference (Vol. 1, No. 1).

[13] Setianingsih, Y. (2019). Nilai Nasionalisme dan Moral dalam Novel Diponegoro dan Perang Jawa Karya Ms Ardian Gajah dan Penerapannya dalam Pembelajaran Bahasa dan Sastra Indonesia. Linguista: Jurnal Ilmiah Bahasa, Sastra, dan Pembelajarannya, 3(1), 50-58.

[14] Setiawan, D. (2013). Peran pendidikan karakter dalam mengembangkan kecerdasan moral. Jurnal Pendidikan Karakter, (1).

[15] Wildan, W. (2013). Kearifan Lokal dalam Novel Seulusoh Karya D. Kemalawat. Bahasa dan Seni: Jurnal Bahasa, Sastra, Seni, dan Pengajarannya, 41(1). 
[16] Zuriah, N. (2011). Model Pengembangan Pendidikan Kewarganegaraan Multikultural Berbasis Kearifan Lokal dalam Fenomena Sosial Pasca Reformasi di Perguruan Tinggi. Jurnal Penelitian Pendidikan, 12(1), 75-86. 